\title{
UJI EFEKTIVITAS EKSTRAK BUNGA KENOP (Gomprhrena globosa L) TERHADAP LUKA BAKAR PADA HEWAN UJI KELINCI (Oryctolagus cuniculus)
}

\author{
Seri Agustini $^{1)}$, Sari Wijayanti ${ }^{2 *}$, Irma Novrianti ${ }^{3}$ ) \\ ${ }^{1}$ Mahasiswa Program Studi D-III Farmasi, Politeknik Kaltara. \\ ${ }^{2,3}$ Program Studi D-III Farmasi, Politeknik Kaltara \\ *Email: sari51wijayanti @gmail.com
}

\begin{abstract}
INTISARI
Tumbuhan yang diyakini oleh masyarakat sebagai tumbuhan obat adalah Bunga kenop (Gomprena globosa L.) diduga mengandung senyawa flavonoid dan saponin yang dapat memodulasi percepatan kesembuhan luka. Bunga kenop telah diteliti dapat memberikan efek penyembuhan luka sayat pada hewan uji, namun sejauh ini belum ada penelitian terkait efektifitas bunga kenop terhadap luka bakar. Sehingga pada penelitian ini bertujuan untuk melakukan identifikasi kandungan senyawa flavonoid dan saponin pada bunga kenop dan melihat efektivitas sebagai penyembuhan luka bakar pada kelinci. Desain penelitian ini adalah penelitian experimental dimana menggunakan 5 kelompok hewan uji yaitu 2 kelompok kontrol, dan 3 kelompok ekstrak bunga kenop. Penginduksian luka bakar dilakukan dengan menggunakan plat $2 \times 2$. Pengukuran panjang luka dilakukan setiap 2 hari sekali selama 14 hari dengan menggunakan jangka sorong. Sedangkan Uji identifikasi senyawa flavonoid dan saponin dilakukan dengan menggunakan metode forth dan wilstater. Berdasarkan hasil penelitian diperoleh bahwa ekstrak etanol bunga kenop mengandung senyawa flavonoid dan saponin. Uji efektifitas ekstrak bunga kenop terhadap luka bakar memberikan hasil bahwa kelompok ekstrak 30\% menunjukan penyembuhan luka $92 \%$ dengan diameter luka pada hari ke-14 0,16; diikuti dengan kelompok ekstrak 20\% dengan persentase kesembuhan luka sebesar $84,3 \%$ dengan diameter luka $0,31 \mathrm{~cm}$. Ekstrak etanol bunga kenop dapat menyembuhkan luka bakar pada konsentrasi tersebut.
\end{abstract}

Kata kunci: Bunga Kenop, Flavonoid, Luka Bakar

\begin{abstract}
The plant that is believed by the public as a medicinal plant is Globe Amarant (Gomprena globosa L) which allegedly contains flavonoids and saponins compounds that can modulate wound healing acceleration. The flower has been shown to have an effect on wound healing in test animals, but so far there has been no research on the effectiveness of the knob flower on burns. Therefore, this study aims to identify the content of flavonoids and saponins in Kenop flowers and to see the effectiveness of healing burns in rabbits. The design of this study was an experimental study that used 5 groups of test animals, namely 2 control groups, and 3 groups of Kenop flower extract. Burn induction was performed using a $2 \times 2$ plate. The length of the wound was measured every 2 days using a caliper. Meanwhile, the identification test of flavonoid and saponin compounds was carried out using the forth and wilstatter methods. Based on the results of the study, it was found that the ethanol extract of the Kenop flower contains flavonoid and saponin compounds. The effectiveness test of the Knob flower extract on burns showed that the $30 \%$ extract group showed $92 \%$ wound healing with a wound diameter on the 14th day of 0.16 ; followed by a $20 \%$ extract group with a wound healing percentage of $84.3 \%$ with a wound diameter of $0.31 \mathrm{~cm}$. The ethanol extract of the flower of the Kenop flower can heal burns at that concentration.
\end{abstract}

Keywords: Kenop Flower, Flavonoids, Burns

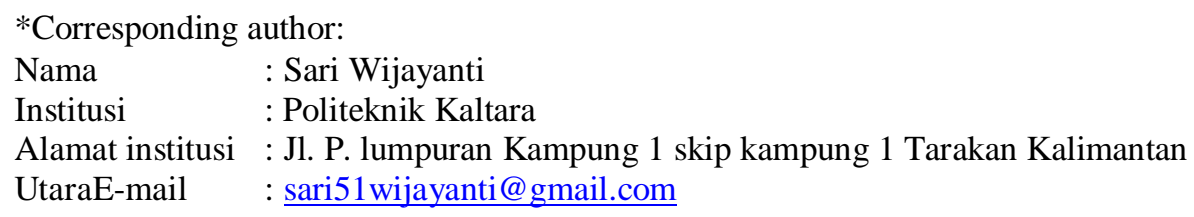




\section{PENDAHULUAN}

Luka adalah keadaan dimana terjadi kerusakan jaringan tubuh yang mengganggu proses seluler normal yang melibatkan jaringan ikat, otot, dan kulit syaraf serta menyebabkan robeknya pembuluh darah sehingga mengganggu hemostatis tubuh. Luka bakar atau combusto adalah suatu kejadian luka yang ditimbulkan oleh sumber panas seperti api, radiasi, air panas, dan listrik yang menyebabkan kerusakan jaringan tubuh. Luka bakar masih merupakan kejadian yang paling sering terjadi di masyarakat dengan angka morbiditas dan mortalitas yang tinggi (Anggraeni and Bratadiredja, 2018; Hendy and Lister, 2019; Oktaviani dkk., 2019; Albadali and Taharuddin, 2020).

Luka bakar juga mengakibatkan kerusakan pada epidermis, dermis, maupun subkutan, serta dalam keadaan yang parah dapat menyebabkan gangguan serius pada paru-paru, ginjal, dan hati (Anggraeni dkk., 2018); selain itu juga dapat mengalami berbagai macam komplikasi yang fatal termasuk diantaranya kondisi syok, yang menyebabkan distress emosional dan psikologis yang berat dikarenakan cacat akibat luka bakar dan bekas luka (Assirri, 2020). Proses penyembuhan lukabakar dapat dibagi tiga fase, yaitu fase inflamasi, proliferasi, dan matururasi. Fase inflamasi berlangsung saat terjadinya luka bakar sampai hari ketujuh, fase poliferasi berlangsung dari akhir fase inflamasi sampai kira-kira akhir minggu ketiga dan fase maturasi berlangsung berbulan-bulan hingga dinyatakan berakhir jika semua tanda radang sudah lenyap (Balqis dkk., 2011).

Penggunaan pengobatan bahan alam saat ini menjadi salah satu terapi alternatif yang tengah berkembang dan diminati oleh masyarakat. Permintaan akan terapi herbal berasal dari persepsi bahwa obat herbal memiliki efek samping yang lebih rendah dibandingkan sediaan konvensional (Prasongko dkk.,2020). Tumbuhan yang di yakini oleh masyarakat sebagai tumbuhan obat adalah Bunga kenop (Gomprena globosa L.). Spesies ini berasal dari Amerika Tengah dan telah menyebar luas ke daerah tropis. Tumbuhan ini dapat dengan mudah ditemukan dikebun rumah sebagai tanaman hias dan telah digunakan selama beberapa generasi oleh masyarakat sebagai obat tradisional (Kusmiati et al., 2017; Esmat and Mittapally, 2020; Herman and Herman, 2020).

Menurut penelitian Priadi dkk (2017), bunga kenop positif mengandung saponin dan flavonoid dimana kedua senyawa ini dapat berperan sebagai antimikroba dan merangsang pertumbuhan sel baru pada luka, sehingga dapat digunakan untuk mengatasi luka bakar. Kandungan senyawa flavonoid dalam bunga kenop memperlihatkan aktivitas bakterisida, antivirus, dan menghambat kerja enzim (Priadi dkk., 2017), dan dapat memodulasi penyembuhan luka (Aslam dkk, 2018). Berdasarkan hasil penelitian bunga kenop dapat digunakan dalam pengobatan luka, seperti luka gangrene pada diabetes (Ilyas dkk., 2014; Esmat and Mittapally, 2020). Menurut penelitian Aji dkk (2019) menunjukan bahwa ekstrak bunga kenop dapat mempercepat penyembuhan pada luka sayat pada hewan uji. Namun sejauh ini belum ada penelitian terkait potensi ekstrak bunga kenop sebagai penyembuhan pada luka bakar. Oleh karena itu penelitian ini diharapkan dapat meningkatkan nilai guna dari tumbuhan liar dalam penggunaannya di kehidupan sehari-hari. Selain itu, penelitian ini juga bertujuan untuk melakukan identifikasi kandungan senyawa flavonoid dan saponin pada bunga kenop dan melihat efektivitas sebagai penyembuhan luka bakar pada kelinci (Oryctolagus cuniculus)

\section{METODE PENELITIAN}

Penelitian ini merupakan jenis penelitian eksperimental dengan design post test only control group. Penelitian ini dilakukan dengan cara mengamati efek ekstrak bunga kenop (Gomphrena globosa L.) terhadap panjang dan persentase penyembuhan luka bakar pada hewan uji kelinci yang dibagi menjadi 5 kelompok yang terdiri dari 2 kelompok kontrol dan 3 kelompok ekstrak. Hasil pengamatan berupa panjang luka bakar dan persentase penyembuhan luka bakar.

\section{Alat dan Bahan}

Alat yang digunakan pada penelitian ini yaitu, Mortir dan Stemper, Blender, Cawan, Batang pengaduk, Kertas Saring ,Pipet tetes, Gelas ukur, Beaker glass,Timbangan analitik, Sudip, Kaca arloji, cutton bud, Jangka Sorong, Kertas perkamen, Toples Ekstraksi, Penangas air dan Panci, Plaster dan kasa, hot plate, Gunting, Pisau (cutter/silet). 
Bahan yang digunakan yaitu Alkohol 96\%, Etanol 96\%, Bunga Kenop, HPMC , Bioplacenton, dan Aquadest.

\section{Pengumpulan bahan baku}

Sampel berupa bunga kenop yang masih muda dan berwarna ungu segar. Kemudian bunga dibersihkan dari kotoran yang masih menempel pada bunga. Selanjutnya dilakukan pencucian dengan dialirkan air bersih, kemudian bunga dikeringkan dengan cara dipanaskan di bawah sinar matahari dengan dilapisi kain berwarna hitam. Bahan dilakukan sortasi kering terhadap bunga yang sudah kering, serta memisahkan bunga dari kotoran yang masih menempel. Selanjutnya bunga diblender sampai berbentuk serbuk lalu ditimbang 350 gram dan dimasukkan ke dalam botol yang dapat melindungi serbuk simplisia tersebut.

\section{Pembuatan Ekstrak}

Ekstrak bunga kenop di peroleh dengan cara maserasi. 350 gram bunga kenop dimasukkan ke dalam botol maserasi yang berwarna gelap, tambahkan pelarut etanol $96 \%$ sebanyak $1800 \mathrm{ml}$ dan diamkan selama 5 hari kemudian di saring. Setelah disaring, hasil maserasi dipekatkan hingga didapatkan ekstrak kental dari bunga kenop.

\section{Identifikasi Senyawa Flavonoid dan Saponin}

1. Flavonoid

1 gram ekstrak bunga kenop ditambahkan dengan 0,1 gram serbuk magnesium $(\mathrm{Mg})$, kemudian tambahkan $\mathrm{HCl}$ pekat secukupnya. Amati perubahan warna

2. Saponin

1 gram ekstrak bunga kenop ditambahkan $10 \mathrm{ml}$ aquades, kocok selama 1 menit. amati timbulnya busa

\section{Pembuatan Gel Ekstrak Bunga Kenop}

Tabel 1. Formula Gel Ekstrak Bunga kenop

\begin{tabular}{cccc}
\hline \multirow{2}{*}{ Bahan } & \multicolumn{3}{c}{ Formulasi (\%) } \\
\cline { 2 - 4 } & F1 & F2 & F3 \\
\hline Ekstrak Etanol Bunga Kenop & 10 & 20 & 30 \\
HPMC & 3 & 3 & 3 \\
Aquades & Add 100 & Add 100 & Add 100 \\
\hline
\end{tabular}

Pembuatan gel ekstrak bunga kenop dimulai dari HPMC yang dikembangkan terlebih dahulu kemudian ditambahkan dengan ekstrak etanol bunga kenop, kemudian diaduk lagi sampai semuanya tercampur atau homogen, disesuaikan dengan masing-masing konsentrasi.

\section{Perlakuan Terhadap Hewan Uji}

\section{Penyiapan Hewan Uji}

Sebanyak lima ekor kelinci yang akan digunakan pada pengujian terlebih dahulu disiapkan dan dikondisikan selama 1 minggu dengan dilakukan penimbangan berat badan kelinci sekali setiap hari sebelum pengujian. Penyiapan hewan uji ini dilakukan agar hewan uji dapat beradaptasi dengan lingkungan baru, mengontrol kesehatan dan menyeragamkan makanannya.

\section{Pembuatan Luka Bakar}

Solder panas dimodifikasi dengan lempeng stainless yang berukuran $2 \times 2 \mathrm{~cm}$. Rambut pada daerah punggung kelinci dicukur, kemudian ditempel solder yang sudah dipanaskan 100 derajat Celcius selama 5 menit, setelah itu ditempelkan pada kulit kelinci (Oryctolagus cuniculus) yang telah dianastesi menggunakan alkohol. Setelah itu dikompres dengan aquadest selama 1 menit. 


\section{Proses pengobatan luka bakar pada punggung mencit}

a. Disiapkan 5 kelompok hewan uji yang terdiri dari 3 kelinci tiap kelompok : kelompok I pemberian kontrol negatif (HPMC), kelompok II ekstrak etanol bunga kenop konsentrasi $10 \%$, kelompok III pemberian ekstrak etanol bunga kenop konsentrasi $20 \%$ dan vaselin flavum, kelompok IV pemberian ekstrak etanol bunga kenop konsentrasi 30\%, kelompok V pemberian kontrol positif (bioplasenton gel).

b. Disiapkan sediaan uji yaitu bioplasenton ${ }^{\circledR}$, gel HPMC, dan ekstrak etanol bunga kenop

c. Pengujian penyembuhan luka dengan :

1) Dioleskan gel HPMC sebanyak 0,1 gram pada kelompok pertama terhadap luka bakar padakulit punggung kelinci.

2) Dioleskan ekstrak etanol Bunga kenop masing-masing 0,1 gram pada kelompok kedua dengan konsentrasi (10\%), ketiga dengan konsentrasi (20\%), dan keempat dengan konsentrasi (30\%) terhadap luka bakar pada kulit punggung kelinci.

3) Dan kelompok kelima dioleskan 0,1 gram bioplasenton® pada kelompok terhadap luka bakar pada kulit punggung kelinci.

\section{Perawatan Luka Bakar Kelinci}

Luka bakar pada kelinci dirawat berdasarkan kelompoknya. Perawatan dilakukan mulai hari ke-1 sampai hari ke-14 sebanyak 2 kali sehari. Luka bakar dirawat secara terbuka hingga sembuh yangditandai dengan merapat dan tertutupnya luka.

\section{Pengamatan Luka bakar}

Pengamatan perubahan luka bakar setiap 2 hari sekali selama 14 hari secara makroskopik pada perkembangan penyembuhan luka di kulit punggung kelinci dan pengukuran panjang luka dengan menggunakan jangka sorong serta dilakukan perhitungan persentase kesembuhan luka.

$$
\begin{array}{|c|}
\text { Panjang luka }=\frac{p 1+p 2}{2} \\
\text { Persentase kesembuhan luka }=\frac{p 0-p x}{p 0} \times 100 \%
\end{array}
$$

Keterangan : $\mathrm{p} 1=$ panjang Luka 1

p2 = panjang Luka 2

po $=$ panjang luka

awal

px panjang luka pada hari tertentu

\section{Analisis Data}

Hasil pengukuran panjang luka dan perhitungan persentase kesembuhan luka akan di Analisis secara statistik dengan menggunakan aplikasi SPSS, dengan uji one way ANOVA dan dilanjutkan dengan uji Post hoc bonferroni dengan tingkat kepercayaan 95\%.

\section{HASIL DAN PEMBAHASAN}

Tumbuhan yang digunakan dalam penelitian ini adalah bunga kenop. Pembuatan ekstrak bunga kenop dilakukan dengan menggunakan metode maserasi, dan menggunakan alkohol 96\% sebagai pelarut. Jumlah ekstrak yang diperoleh adalah 8,4 gr ekstrak bunga kenop dari 350 gr simplisia kering, sehingga diperoleh persentase randemen ekstrak adalah 2,4\%. 


\section{Identifikasi Senyawa Saponin dan Flavonoid}

Uji identifikasi flavonoid yang terkandung dalam bunga kenop dilakukan dengan menggunakan metode forth dan wilstater. Dengan menambahkan 0,1 serbuk Magnesium $(\mathrm{Mg})$ dan sedikit $\mathrm{HCl}$ pekat terhadap larutan ekstrak bunga kenop. Hasil uji menunjukan adanya perubahan menjadi warna kuning kemerahan. Hal ini menunjukan bahwa terdapat senyawa flavonoid dalam larutan ekstrak bunga kenop. Perubahan warna ini terjadi karena adanya pembentukan garam Flavilium yang berwarna merah-jingga sebagai reaksi dari ikatan gugus karbonil flavonoid dengan $\mathrm{Mg}$ dan $\mathrm{HCl}$ (Afriani dkk, 2016). Uji saponin dilakukan dengan menggunakan metode forth (Afriani dkk, 2016). Dengan menambahkan aquades $10 \mathrm{ml}$ ada tabung reaksi yang berisikan ekstrak dan kemudian dikocok. Hasil uji menunjukan adanya busa setinggi $1 \mathrm{~cm}$, hal ini menunjukan bahwa adanya kandungan senyawa saponin dalam esktrak bunga kenop. Hasil uji identifikasi senyawa flavonoid dan saponin dapat dilihat pada tabel 2.

\section{Tabel 2. Hasil Skrining Fitokimia dari Ekstrak Etanol Bunga kenop}

\begin{tabular}{clc}
\hline Uji & \multicolumn{1}{c}{ Hasil Positif } & Hasil \\
\hline Flavonoid & $\begin{array}{l}\text { Terbentuknya Larutan kuning } \\
\text { kemerahan } \\
\text { Saponin }\end{array}$ & $\begin{array}{l}\text { Terdapat busa } 1 \quad \mathrm{~cm} \text { yang } \\
\text { bertahan selama 10 menit }\end{array}$ \\
\hline
\end{tabular}

\section{Uji Aktivitas Ekstrak Etanol Bunga Kenop Terhadap Panjang Luka bakar dan persentase Penyembuhan Luka Bakar Pada Kulit Punggung Kelinci}

Pengujian dilakukan secara bersamaan antara 5 kelompok yaitu kelompok kontrol negatif, kelompok ekstrak bunga kenop dengan tiga konsentrasi berbeda $(10 \%, 20 \%$, dan 30\%), dan kontrol positif. Penggunaan 3 konsentrasi yang berbeda pada penelitian ini bertujuan untuk mengetahui konsentrasi minimal dari ekstrak etanol bunga kenop yang dapat menyembuhkan luka bakar kelinci. Semua sediaan uji dibuat dalam 2 g stok gel untuk persediaan 7 hari. Hewan uji masing- masing diberikan dosis sebanyak $0,1 \mathrm{~g}$ untuk sekali oles sebanyak 2 kali sehari. Sebelum dilakukan pengujian, hewan uji terlebih dahulu diadaptasikan selama 1 minggu, hal ini bertujuan agar kelinci dapat menyesuaikan diri terhadap lingkungan baru (Aji dkk., 2019).

Uji efektifitas pada penelitian ini dimulai dari mencukur bulu bagian punggung kelinci, hal ini bertujuan agar mempermudah pengukuran area dan ketika dilakukan penginduksian langsung mengenai kulit kelinci. Luka bakar pada kelinci dilakukan dengan menempelkan plat logam panas ukuran $2 \times 2 \mathrm{~cm}$ selama 5 detik pada punggung kelinci yang sebelum nya di anastesi dengan alkohol. Anastesi bertujuan untuk mengurangi nyeri saat perlukaan, dan membersihkan atau mensterilkan area yang akan dilukai (Elmitra dkk., 2017). Kulit yang mengalami luka bakar akan diberikan perlakuan sesuai dengan kelompoknya masing-masing. Pengamatan ukuran luka dilakukan secara visual dan pengukuran panjang luka setiap 2 hari sekali dengan menggunakan jangka sorong. Luka dinyatakan sembuh apabila semakin mengecilnya ukuran luka, luka mengering secara merata hingga luka tertutup jaringan kulit. Pengamatan dan pengukuran luka dilakuakan selama 14 hari.

Luka pada hari pertama dan kedua setelah pemberian ekstrak bunga kenop terlihat belum kering dan masih basah, karena luka masih berada dalam fase koagulasi. Fase ini merupakan kondisi luka setelah terjadi perdarahan yang diikuti oleh aktifitas kaskade pembekuan darah dan membentuk klot hematoma (Vijayaraghavan dkk., 2017). Setelah 7 hingga 8 hari perlakuan luka tampak mengering, hal ini dikarenakan luka masuk pada fase poliferasi. Fase ini adalah fase dimana keratinosit yang berada disekitar luka akan mengalami perubahan fenotif yang akan menyebabkan neovaskularisasi dan pembentukan jaringan granulasi baru. Pada fase ini akan memproduksi kolagen yang dapat menarik sel epidermis yang berasal dari tepi luka menuju ke tengah luka, sehingga ukuran luka akan berkurang atau mengecil. Selain itu pada fase ini juga akan terjadi pembentukan pembuluh darah baru. Fase poliferasi pada luka terjadi pada hari ke 4 sampai ke 21 (Landén dkk., 2016; Vijayaraghavan dkk., 2017). 
Berdasarkan grafik pada gambar 1, dapat dilihat bahwa panjang luka bakar di hari ke-14 paling besar ditunjukan oleh kelompok kontrol negatif dan kelompok ekstrak $10 \%$ yaitu masingmasing 1,21 cm dan 1,09. Hal ini disebabkan karena kontrol negatif tidak memiliki zat aktif sedangkan kelompok ekstrak 10\% sedikit mengandung ekstrak bunga kenop sehingga tidak memberikan efek penyembuhan luka yang optimal pada hewan uji (Aji dkk., 2019).

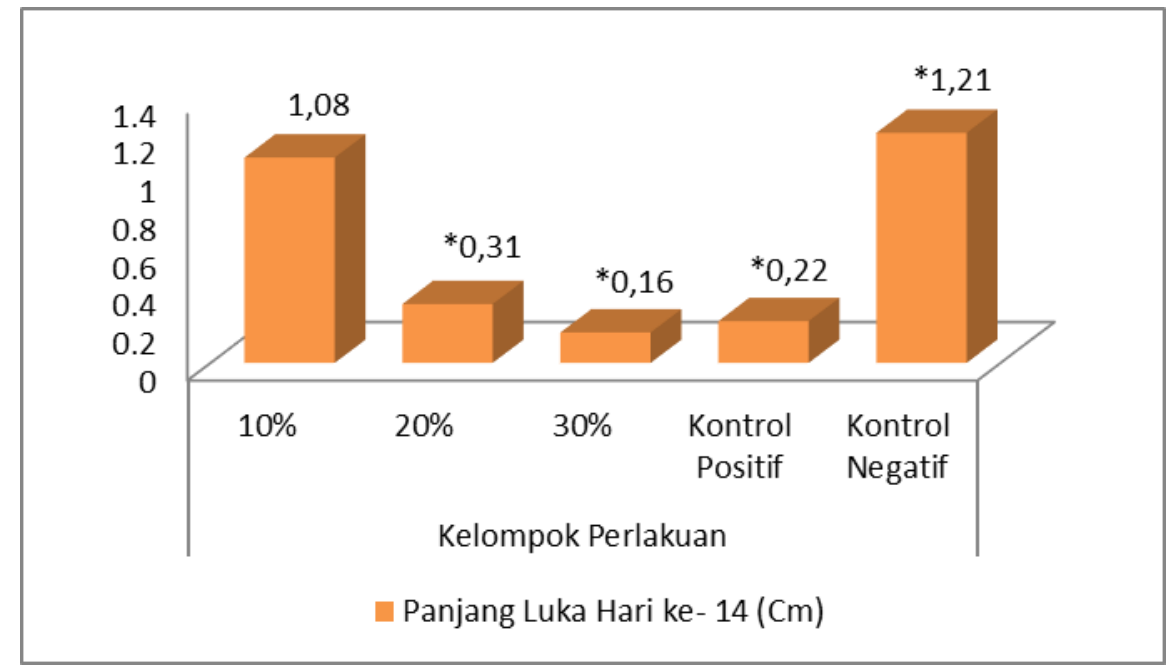

* Terdapat perbedaan signifikan terhadap terhadap kontrol negatif

Gambar 1. Grafik Ukuran Panjang Luka

Berdasarkan hasil penelitian pada gambar 1, yang membandingkan kelompok perlakuan (X) dan panjang luka pada hari ke-14 (Y), menunjukan bahwa ekstrak 10\% dan kontrol negative memiliki efek yang tidak berbeda secara signifikan dengan nilai $\mathrm{p}>0,05$, panjang luka kelompok ekstrak $10 \%$ adalah $1,08 \mathrm{~cm}$ dan kelompok kontrol negative adalah $1,21 \mathrm{~cm}$. Hasil yang berbeda ditunjukan oleh kelompok ekstrak $20 \%$ dan 30\% dimana menunjukan efek yang berbeda secara signifikan dengan kelompok kontrol negative dimana kelompok ekstrak $20 \%$ dan ekstrak $30 \%$ menunjukan panjang luka yang lebih kecil dibandingkan kontrol negative dengan nilai $\mathrm{p}<0,05$. Kelompok kontrol positif juga memiliki efek yang berbeda dengan kontrol negative dan kelompok ekstrak $10 \%$ dengan nilai $\mathrm{p}<0,05$ dimana panjang luka kontrol positif lebih kecil dibandingkan kontrol negative dan kelompok ekstrak 10\%. Hal berbeda ditunjukan oleh kelompok ekstrak 20\%, $30 \%$ dan kontrol positif dimana memberikan efek yang sama atau tidak menunjukan perbedaan yang sigifikan terhadap panjang luka pada hewan uji dengan nilai $\mathrm{p}<0,05$. Dengan adanya hal ini dapat disimpulkan bawah semakin tinggi konsentrasi ekstrak maka semakin kecil juga panjang luka bakar pada hewan uji.

Efek ini juga berbanding lurus dengan persentase kesembuhan luka. Dari hasil uji statistik perhitungan persentase kesembuhan luka diperoleh hasil bahwa kelompok ekstrak 10\% memiliki persentase kesembuhan luka yang tidak berbeda signifikan dengan kontrol negatif, dan menunjukan perbedaan yang signifikan dengan kontrol positif hal ini menunjukan bahwa efektivitas ekstrak $10 \%$ tidak jauh berbeda dengan kontrol negative dengan nilai $\mathrm{p}>0,05$. Kelompok esktrak $20 \%$ dan $30 \%$ memiliki perbedaan yang signifikan dalam persentase kesembuhan luka dengan kontrol negatif, dimana persentase kesembuhan kelompok ekstrak 20\% dan 30\%, 2 kali lebih besar dibandingkan kelompok kontrol negative dengan nilai $\mathrm{p}<0,05$. Persentase penyembuhan luka bakar pada kelompok ekstrak 20\%, 30\% dan kontrol positif tidak menunjukan hasil yang berbeda secara statistik. Dimana kelompok ekstrak $20 \%$ menunjukan persentase kesembuhan sebesar $84,3 \%$, sedangkan kelompok kontrol positif menunjukan persentase kesembuhan adalah $88,8 \%$ dan kelompok ekstrak $30 \%$ memiliki pesentase tingkat kesembuhan luka pada hari ke 14 lebih besar dibandingkan kelompok lainnya sebesar $92 \%$. 
Hal ini disebabkan kelompok ekstrak 30\% memiliki kandungan ekstrak bunga kenop paling besar sehingga menimbulkan efek penyembuhan yang lebih kuat dibandingkan kelompok kontrol negatif dan kelompok ekstrak 10\% (Izzati, 2015; Siahaan and Chan, 2018). Hal ini menunjukan bahwa semakin tinggi konsentrasi ekstrak maka semakin besar persentase kesembuhan luka bakar pada hewan uji. Hal ini sejalan dengan penelitian Aji dkk (2019) dan Prasongko dkk (2020), dimana kelompok yang kandungan konsentrasi ekstrak nya lebih besar menunjukan efek kesembuhan luka paling besar.

Dari hasil pengukuran panjang luka dan perhitungan persentase kesembuhan luka dilakukan uji statistik dengan menggunakan One Way Anova. Hasil uji One Way Anova menunjukan nilai signifikansi $\mathrm{p}<0,05$ hal ini menunjukan adanya perbedaan panjang luka bakar pada seluruh kelompok.

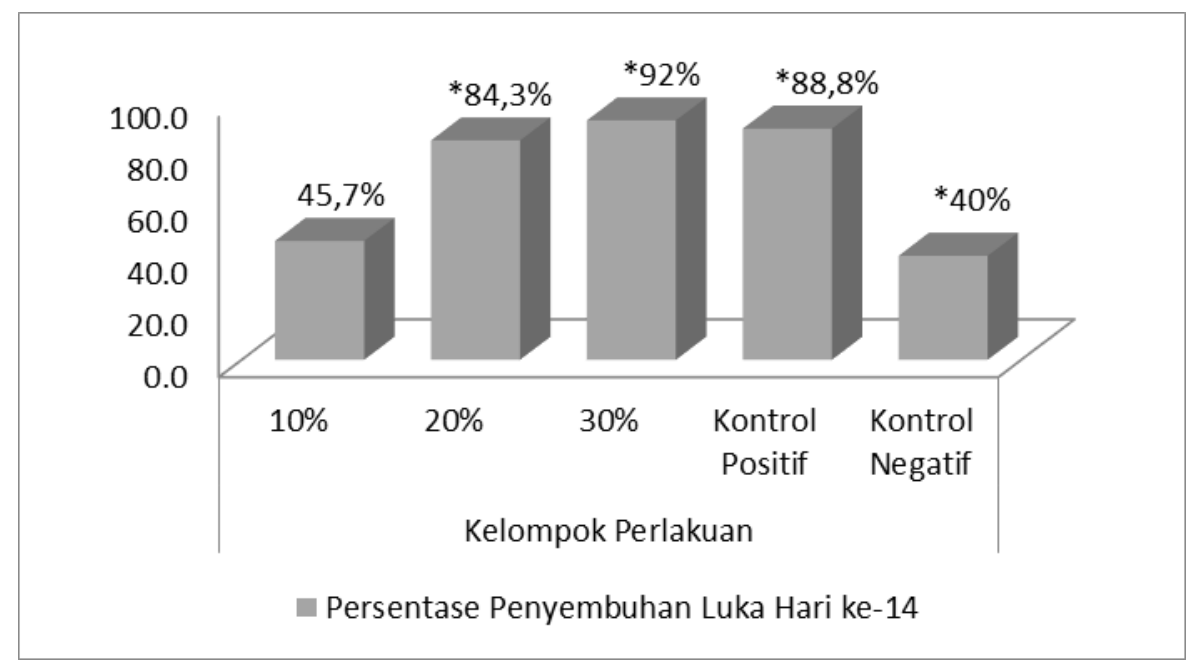

*Terdapat perbedaan signifikan terhadap terhadap kontrol negatif

Gambar 2. Rerata Persentase Penyembuhan Luka pada hari ke-14

Berdasarkan penelitian ini menunjukan bahwa ekstrak bunga kenop memberikan efektifitas kesembuhan luka bakar. Hal ini tidak dapat lepas dari kandungan dari bunga kenop sendiri yang terbukti dari hasil uji indentifikasi senyawa, dimana positif mengandung flavonoid dan saponin. Flavonoid dan saponin yang telah terbukti dapat menyembuhkan luka dan sebagai anti inflamasi (Burnstock dkk., 2012; Nahid dkk., 2016; Aji dkk., 2019). Katekin adalah salah satu kelas flavonoid yang paling banyak digunakan untuk memodulasi penyembuhan luka (Aslam dkk 2018).

Penyembuhan luka terjadi sebagai reaksi feedback seluler terhadap kerusakan kulit, dimanamelibatkan instigasi fibroblas, sel endotel dan makrofag. Pemulihan struktur dan fungsi sel daerah luka dipengaruhi oleh proliferasi fibroblas. Meskipun daerah luka dapat pulih secara alami dengan mekanisme perbaikan spesifik tubuh, namun agen terapeutik mampu merangsang dan mempromosikan sel proliferasi. Senyawa fitokimia seperti senyawa flavonoid yang terkandung dalam tumbuhan dapat meningkatkan proliferasi sel dan migrasi sel fibroblast (Zain dkk., 2020). saponin.

Selain flavonoid senyawa yang dapat mempercepat penyembuhan luka bakar adalah Saponin mempengaruhi perbaikan jaringan pada tahapan awal luka dengan cara menghambat produksi jaringan luka yang berlebih sehingga mengurangi penggumpalan darah. Selain itu saponin dapat berperan sebagai antimikroba, meningkatkan sistem kekebalan tubuh, dan dapat mempercepat penyembuhan luka karena dapat merangsang pembentukan sel epitel baru. Selain itu saponin juga dapat mengurangi resiko infeksi pada luka bakar karena dapat berperan sebagai antiseptik sehingga dapat mencegah pertumbuhan dan membunuh mikroorganisme di daerah luka (Aji dkk., 2019). 


\section{KESIMPULAN}

Ekstrak etanol bunga kenop memberikan efek penyembuhan luka bakar pada konsentrasi $20 \%$ dan 30\% dengan panjang luka bakar pada hari ke-14 masing-masing $0,16 \mathrm{~cm}$ dan $0,31 \mathrm{~cm}$ dengan persentase kesembuhan luka sebesar 84,3\% untuk kelompok ekstrak $20 \%$ dan $92 \%$ untuk kelompok ekstrak $30 \%$. Golongan senyawa yang terdapat dalam ekstrak etanol bunga kenop adalah flavonoid dan saponin.

\section{UCAPAN TERIMA KASIH}

Terima kasih kami ucapkan kepada Direktur dan Ketua Program Studi D-III Farmasi Politeknik Kaltara, serta Kepala Laboratorium dan laboran di laboratorium Farmakologi Politeknik Kaltara. Serta semua pihak yang telah banyak membantu dalam berlangsungnya penelitian ini.

\section{DAFTAR PUSTAKA}

Afriani, N., Idiawati, N., and Alimudin, A. H (2016) 'Skrining Fitokimia dan Uji Toksisitas Ekstrak Akar Mentawa ( Artocarpusanisophyllus ) Terhadap Larva Artemia salina', Jurnal Kimia Khatulistiwa, 5(1), pp. 58-64.

Aji, N. P. A., Sani, F. and Dewi, H. K. (2019) 'Uji Efektifitas Ekstrak Bunga Kenop (Gomphrenaglobosa L.) Terhadap Penyembuhan Luka Sayat Pada Kelinci (Oryctolagus cuniculus)', Jurnal Ilmiah Farmacy, 6(2), pp. 338-344.

Albadali, A. R. and Taharuddin, T. (2020) 'Efektifitas Pemberian Daun Binahong (Anredera cordifolia (Ten.) Steenis) terhadap Penyembuhan Luka Diabetes Mellitus pada Tikus: LIterature Review', Borneo Student Research (BSR), 2(1), pp. 203-208.

Anggraeni, L. and Bratadiredja, marline abdassah (2018) 'Tanaman Obat Yang Memilki Aktivitas Terhadap Luka Bakar', Farmaka universitas padjadjaran, 16(2), pp. 222-230.

Aslam, M. S., Ahmad, M., Riaz, H., Raza, S., Husain, S., Qureshi, O., Maria, P., Hamzah, Z., and Javed, O., (2018) 'Role of Flavonoids as Wound Healing Agent', Phytochemicals - Source of Antioxidants and Role in Disease Prevention, (November 2018). doi: 10.5772/intechopen.79179.

Assirri, aggung. E. (2020) 'Efek Buah Kiwi (Actinidia Deliciosa ) Sebagai Pengobatan Luka Bakar Derajat II Pendahuluan', 11(1), pp. 585-590. doi: 10.35816/jiskh.v10i2.352.

Balqis, U. Masyitha, D. And Febrina, F. (2011) 'Healing Process Of Burns Using Ambarella Leaf (Spondias dulcis F .) andVaselin in Rats', jurnal Medika Veterinaria, pp. 9-14.

Burnstock, G., Knight, G. E. and Greig, A. V. H. (2012) 'Purinergic signaling in healthy and diseased skin', Journal of Investigative Dermatology, 132(3 PART 1), pp. 526-546. doi: 10.1038/jid.2011.344.

Elmitra, E. et al. (2017) 'Uji Efektifitas Gel Ekstrak Buah Tomat (Lycopersicum esculentum Mill) Terhadap Luka Bakar Superfisial Kelinci Jantan Putih', Scientia: Jurnal Farmasi dan Kesehatan, 7(2), p. 134. doi: 10.36434/scientia.v7i2.129.

Esmat, A. U. and Mittapally, S. (2020) 'a Review on Gomphrena Globosa (L)', International Journal of Research in Ayurveda and Pharmacy, 11(3), pp. 78-84. doi: 10.7897/22774343.110366.

Hendy, H. and Lister, I. N. E. (2019) 'Tingkat Efektivitas Penyembuhan Luka Bakar Derajat IIA dengan Pemberian Madu dan Pemberian Salep Nebacetin pada Tikus Putih (Rattus Norvegicus)', Jurnal Kedokteran dan Kesehatan, 15(2), p. $130 . \quad$ doi: 10.24853/jkk.15.2.130- 134.

Herman, A. and Herman, A. P. (2020) 'Herbal Products for Treatment of Burn Wounds', Journal of burn care \& research: official publication of the American Burn Association, 41(3), pp. 457-465. doi: 10.1093/jbcr/iraa010.

Ilyas, M., Tarnam, A. and Begum, N. (2014) 'Biological potential and phytopharmacological screening of Gomphrena species', Global Journal of Pharmacology, 3(1), pp. 58-66. 
Izzati, U. Z. (2015) 'Efektifitas Penyembuhan Luka Bakar Salep Ekstrak Etanol Daun Senggani (Melastoma malabathricum L .) Pada Tikus ( Rattus norvegicus )', Program Studi Farmasi, Fakultas Kedokteran, Universitas Tanjung Pura Pontianak, p. 6.

Kusmiati, K., Priadi, D. and Rahayu, R. K. B. R. (2017) 'Antibacterial Activity Test, Evaluation of Pharmacognosy and Phytochemical Screening of Some Extracts of Globe Amaranth (Gomphrena globosa)', The Journal of Pure and Applied Chemistry Research, 6(1), pp. 27 33. doi: 10.21776/ub.jpacr.2017.006.01.288.

Landén, N. X., Li, D. and Ståhle, M. (2016) 'Transition from inflammation to proliferation: a critical step during wound healing', Cellular and Molecular Life Sciences, 73(20), pp. 3861- 3885. doi: 10.1007/s00018-016-2268-0.

Nahid, J. Bahmani, M. and Asadi-samani, M. (2016) 'A review of the most important medicinal plants effective on wound healing on ethnobotany evidence of Iran', $J$ Inj Inflam, 1(2), pp. $7-8$.

Oktaviani, D. J. Widiyastuti., Maharani, D., Amalia, A., Ishak, M., dan Zuhrotun, A., (2019) 'Review: Bahan Alami Penyembuh Luka', Farmasetika.com (Online), 4(3), p. 44. doi: 10.24198/farmasetika.v4i3.22939.

Prasongko, E. T., Lailiyah, M. and Muzayyidin, W. (2020) 'Formulasi dan Uji Efektifitas Gel Ekstrak Daun Kedondong (Spondias dulcis F) Terhadap Luka Bakar pada Tikus Wistar (Rattus novergicus), Farmasi, S Farmasi, Fakultas Ilmu, Institut Bhakti, Kesehatan, 007, pp. 27-36.

Priadi, D. and Rahayu, R. K. B. (2017) 'Antibacterial Activity Test, Evaluation of Pharmacognosy and Phytochemical Screening of Some Extract of Globe Amaranth ( Gomphrena globosa )', 6(January), pp. 27-33. doi: 10.21776/ub.jpacr.2017.006.01.288.

Siahaan, A. V. and Chan, A. (2018) 'Burn Medicine Gel Formulation of Ethanol Extract of Pegagan Leves ( Centella asiacita L . ) and Papaya Leaves (Carica papaya L)', Jurnal Dunia Farmasi, 2(2), pp. 59-69.

Vijayaraghavan, K., Rajkumar, J. and Seyed, M. A. (2017) 'Efficacy of Chromolaena odorata leaf extracts for the healing of rat excision wounds', Veterinarni Medicina, 62(10), pp. 565578. doi: 10.17221/161/2016-VETMED.

Zain, M. S. C. Soo Yee Lee 1, Sarian, M., Shaari, K., Fakurazi, S., 2020) 'In vitro wound healing potential of flavonoid c-glycosides from oil palm (Elaeis guineensis jacq.) leaves on 3t3 fibroblast cells', Antioxidants, 9(4). doi: 10.3390/antiox9040326 